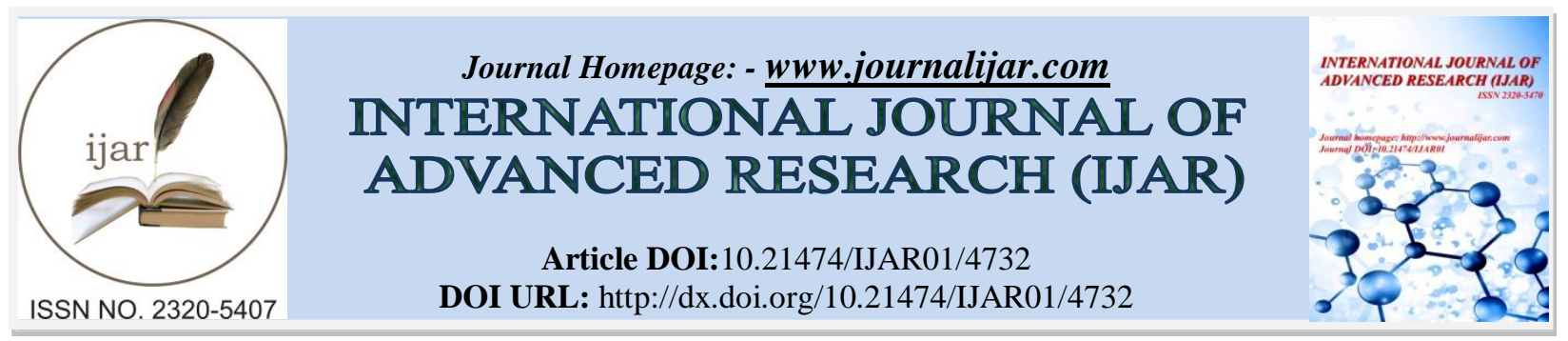

RESEARCH ARTICLE

\title{
CONSTRUCTION ON REGULATIONS FOR SETTING UP \& RUNNING AN INTEGRATED CLINIC LABORATORY: (A DIGNIFIED JUSTICE PERSPECTIVE).
}

Edward Kurnia Setiawan L ${ }^{1}$, Prof. Dr. Teguh Prasetyo SH. M. Si ${ }^{2}$ and Dr. H. Jawade Hafidz S. H. M. H ${ }^{3}$.

1. Doctoral Student at the Faculty of Law Sultan Agung Islamic University, Semarang Central Java-Indonesia) and a Staff at the Clinical Pathological Department Faculty of Medicine Diponegoro University Central JavaIndonesia.

2. Faculty of Law Universitas Kristen Satya Wacana Salatiga Central Java-Indonesia) and Resently has been Appointed by the President of the Republic of Indonesia as the Commisioner for the Republic of Indonesia's Court of Ethichs for the General Election Organizers.

3. Faculty of Law Sultan Agung Islamic University, Semarang Central Java-Indonesia.

\section{Manuscript Info}

Manuscript History

Received: 4 May 2017

Final Accepted: 6 June 2017

Published: July 2017

Key words:-

Regulalations, Integrated Clinic

Laboratory, Justice, Pancasila

\section{Abstract}

Reconstruction on regulations and implementation of the regulations on the setting up and running of the integrated clinic laboratory (klinik dalam klinik) in this research is based on the virtue of justice which reflecting the Pancasila as the spirit of the Indonesian people (Volksgeist) revolved mainy in the ministerial regulations. The result of the reconstruction has found, that in the Pancasila Legal System the implementation of the regulations governing the setting up and running of the integrated clinic laboratory is to some extend in accordance with the laws. That is according to the Ministery of Health Regulation Number 9 of 2014; the Ministery of Health Regulation Number 411/MENKES/PER/X/2010 regarding Clinic Laboratory and the Ministery of Health Regulation Number 43 of 2013 on the Good Running of Clinic Laboratory. All of the Ministery of Health Regulations have stated rules governing a standardized clinic laboratory on aspects such as facilities and infrastuctures, manpower, management, and procedures to set up and run the clinic laboratory.

Copy Right, IJAR, 2017,. All rights reserved.

\section{Introduction:-}

This paper is a result of the reconstruction on the regulations of the setting up and running of the what so called integrated clinic laboratory (klinic dalam klinik) in Indonesia. It is argued from the Dignified Justice perspective that the implementation on the regulations governing the integrated clinic laboratory have been adjusted with the demand of the laws or justice virtues as reflected as the spirit of the people (Volksgeist) in the Pancasila Legal System which are mainly revolved around the Ministery of Health of The Republic of Indonesia (Permenkes) Regulation Number 9 of 2014; the Ministery of Health of The Republic of Indonesia Regulation Number 411/MENKES/PER/X/2010 on the Clinic Laboratory and the Ministery of Health of The Republic of Indonesia Regulation Number 43 of 2013 on the Good Running of Clinic Laboratory.

Corresponding Author:-Edward KurniaSetiawan L.

Address:-Doctoral Student at the Faculty of Law Sultan Agung Islamic University, Semarang Central Java-Indonesia) and a Staff at the Clinical Pathological Department Faculty of Medicine Diponegoro 


\section{The Constitutional Basis of the Ministerial Regulations:-}

Reconstruction of the ninisterial regulations on the integrated clinic laboratory has found that all of laws, particularly the ministerial regulations governing the setting up and the running of the clinic laboratory are based on the principles dictated in the Indonesian Constitution. It is clearly stated in the Article 24 section (1) until section (6) of the Ministery of Health of The Republic of Indonesia Regulation Number 9 of 2014 on Clinic Laboratory that all of the regulatons in these aspects have to based on and not contradicting or in conflic with the more higher laws.

The research has indicated that the highest law which has been reffered to in the Ministery of Health of The Republic of Indonesia Regulations is the clause governing the people's rights to health services as stated in the Republic of Indonesia Basic Act 1945 (UUD 1945). It is stipulated in the Article 28H, section (1) and (3) of the Constitution that: "every person has the right to a prosperious life in body and in soul, to have a proper dwelling, and to live in a good environment as well as having rights to health services." Related to such a constitutional rights, it has also been stipulated in the Constitution, particularly at the section (3) of the Article that: "every person has the rights to social security which would enable each person to develop his/or her human life as an integral dignified human being".

Inspired by the dictate of the Constitution as stated above, the research has also found that it has been formulated in the Article 41 of the Act Number 39 of 1999 on Human Rights that each citizen has the rights to have social security to a proper live and self development integratedly. Furthermore in the Article 49 section (2) it has been stated a guaranty for the provision on safety and health of woman and their reproduction function when they are on their employment and/or profession. Article 62 of the same Act contain the children rights to health.

Further detailed rights of children has also added in Article 128 to 135 of the Health Act. It has been stipulated there that every child has the rights on health services and proper social security to support their physical need as well as spirituals. The latest Act, i.e. the Law Number 36 of 2009 on Health has also contained a stipulation that every person has an equal rights to obtain every necessities with regards to their health. The Act has also stated a fundamental principle that the rights of every person to have a health service is the obligation of the Government. This principle has been stated in Article 14 to Article 20 of the Health Act.

The research has also found one significant rule of justice in Article 2 of the Law Number 36 of 2009 on Health and also Article 2 of the Law Number 44 of 2009 on Hospital with regards to the health service. It reads that, the running of health services, and in this regards the setting up and running of the integrated clinic laboratory must be fair and equal and having its financing being reachable by the society as a whole. Article 2 of the Law of Republic of Indonesia Number 11 of 2009 on the Social Welfare has also stipulated the same principle, that the principle of justice is a necesity in the running of the social health services and must have its stressing in the equality aspect, indiscriminated principle and also balance between rights and obligations.

\section{Integrated Clinic, Its Place in the Clinical Category:-}

Based on the juristic elaborations as mentioned above, modern health services in Indonesia must be implemented with the involvement of clinic, within it a clinic laboratory is a legal requirement must be set up and runn as the obligation demands by the law. It is due to that legal fact that clinic is one of the centre of health in the Pancasila Legal System. Clinic is running either by individuals or businesses.According to the Article 4 section (2) of the Ministery of Health Regulations on Clinic, there are two categories of clinic. The first category of clinic is called preliminary (premium) clinic. In this category, the health services (including the clinic laboratory as its part) has to be provided and undertake by a qualified general medical doctor (GP).

The second category of clinic is named as the main clinic. In this second category of clinic, the healt services provided (and including within it the clinic laboratory as its part) are conducted by specialists doctors and also the GP. Apart from the existence of a clinic laboratory, within the two categories of clinics, there should be provided health services such as temporary hospital care (rawat jalan), intensive overnight hospital care (rawat inap), pharmacy or drug store, and radiology ect. This writer would argue that the what so called integrated clinic (klinik dalam klinik) could find its place within the first and the second category of clinic as described above.

Based on a data issued by the Central Java-Indonesia's Health Authorities, recently in the Central Java region, there have been about 888 clinics. These clinics could further be divided into 15 clinics which were own and runn by the Military/or Police, one clinic runn by a State Company $(B U M N)$ and 871 clinics were set up and running by private 
bussinises. ${ }^{1}$ There have been more then 131 clinics made a joint cooperation with the National Body for Health Insurance $(B P J S){ }^{2}$ Research has shown that all the clinics (131 clinics) do not understand that there has been a rule of law to be complied with. That is the rule which dictates that every clinic must have their own laboratory service department. As the instalment of laboratory is a costly and expensive arragement, many premium clinics have decided to integrate themselves into main clinics to comply with the legal requirement, i.e., "must have had a laboratory department within the clinic".

Althought it has been stated in the governemnt regulations that clinic laboratory is an inherent part of a clinic, the law has given a sorth of leniency that the instalment of the laboratory in a clinic must be done with the consideration of the manegement ability cope with its financing capacity. The law however, are strict in its tone when a clinic is a main clinic, in which it must have providing service for intensive care in the clinic. Clinic laboratory in the premium category of clinic should be set up and runn as a basic health service. Meanwhile the second category of clinic, the main clinic, can set up and runn a clinic laboratory service jointly with the premium clinic or medium one.

This has created problem in the licencing being granted by the licencing authority, and also its control by the local gevernment authority. Due to the fact that there are appear to be two clinic laboratories in one clinic, as suggested by the law, but in fact only one exist. This however, has been regulated in the Article 24 section (5) of the Ministery of Health Regulation on Clinic.

In principle, according to the law, a clinic can undertake to instal a clinic laboratory based on its financial capacity. This writer would argue that this is the justice aspect in the ministerial regulations on the setting up and running an integrated clinic (klinik dalam klinik). The practice of integrating a lower level of clinic category into a high level one is fairness, in a sense according to the spirit of law mentioned in the Ministery of Health Regulation Number 411/MENKES/PER/III/2010 on Clinic Laboratory.

The instalment of a clinic laboratory unit in a clinic must fulfill several conditions stated in the Ministerial Regulation. There are four requirements. Firstly, the clinic must have its own premis property, location, utilities and infrastructures, qualified manpower as a medical aparatus such as doctors or specialist doctors and also nurses and other medical and administrative staff. All of these requirements are legal requirements, and that means that all of them must be fulfilled in order to be legally qualified as a clinic.

As for the own premise requirement, it has been regulated that the size of a clinic laboratory must be spacious enough in order to be able to cope with all of the equipments and facilities and also the infrastructure to support the operational of the clinic laboratory and the clinic. As for the requirement of qualified manpower, the law has given it as a prioroty that the man power must first of all having the competency (certified staff) in order to runn the operational of the laboratory. In other words, there must be in the clinic a qualified person to implement the controling function of the operational of the laboratory, internally.

Moreover, it has been stipulated in the Ministery of Health Regulation that it is a formal requirement for every clinic, including the an integrated clinic laboratory to have a person who bear the responsibility of its operation, and it has been stated clearly that the person should be a doctor. The doctor must have undertaken a technical training minimum 3 years and also having a health management capability (certified) minimum 3 months in the subject of running a clinic laboratory. The training must have been conducted by a pathological clinic profession. It is suggested within the law that the person who hold the responsibility of the running of the laboratory in the medium category of clinic must be a doctor who has the expertice in the clinical pathology.

As mentioned above, that the regulation on the setting up and running of clinic laboratory in a clinic is not against the law. Eventhough, in fact, the research has found that the licence of an integrated clinic is not in line with the requirement of the law. Several clinic laboratory has the person who hold the responsibility as a doctor but does not holding the requirement as stated above. The local gobernment who has the responsibility to observe the compiance with the law has just ignoring this situation.

\footnotetext{
${ }^{1}$ DinasKesehatanProvinsiJawa Tengah, BukuProfilKesehatanProvinsiJawa Tengah tahun 2012, h. 241.

${ }^{2}$ Andayani Budi Lestari, 2014, Pelaksanaan JKN oleh BPJS KesehatanBulanJanuari 2014, RakerkesdaDinasKesehatanProvinsiJawa Tengah Tahun 2014.
} 
The research has also found that the medical staff who runn the laboratory in the clinic is not having the expertice in the laboratory. In fact the person has just a senior high school gradute or the like, or a nurse who has been getting involved with the handeling of the day to day bussiness of a laboratory for many years. This will cause a problem with the quality of the service of the laboratory in the clinic either externally and internally. Appart from it, there has been problem with the spaciousness of the premise required by the law. In other words there still many problem correspond with the requirement of the formal regulations in the setting up and running of a clinic, in which there must be a clinic laboratory.

As the law has clearly stated that the conditions for the setting up and the running of a clinic must comply with the place or premise of the laboratory, the manpower, the procedurals to use spesiment, quality control, laboratory management and the like. All of these have to be complied with in order to make sure the quality of the health service given by a clinic laboratory. In these regards the management of a clinic starting from taking spesimen up to diagnosing and ending with the result of the laboratory process will be done properly. As the standard has dictated, among other things, that a good result from laboratory process will produce a good medical record of the patient and in turn legally will be usefull as an evidence for a court process, should a legal dispute arise in the medical service. This principle of justice has been stated in the Ministery of Health Regulation Number 43 of 2013 on the Good Running of Clinic Laboratory.

Despite the facts as shown above that the two category of clinic laboratory can be integrated as one clinic laboratory. Ideally, it is necessary to argue here that an existence of an independent clinic laboratory in the premium category of clinic. A clinic laboratory separate from a clinic has been understood in this paper so far as not an integrated clinic laboratory, and must be governed by a separate system of regulations. As it must be acknowleged that there have been different in the purpose behind the setting up and also the running of the two different category of clinic laboratories. In another words one could argue that the separate category of clinic laboratory have their own standards operations.

The problem is untill now, the general policy to accomodate the demand as stated above must facing the real facts the there has been no proper regulation to govern the separation of the two types of clinic laboratory in Indonesia. This situation is the main cause and also justification for the existence of the integrated clinic laboratory (klinik dalam klinik). So far the setting up and also running of the two clinic in one clinic laboratory having its legal basis on the Ministery of Health Regulation on the Clinic Laboratory which in fact allow this to happen. Therefore it is urgent to have a harmonization on the regulations governing the clinic laboratory. The harmonization of the regulations have to make sure that there is no conflict vertically and also horizontally between the regulations in the same field. Appart from it, the harmonization of regulations project must be made in order for the players in the clinic laboratory to have legal certainty with regards to the policies in this particular field in the Indonesian system.

As stated above, the law which governing the setting up and also running of clinic laboratory or the integrated clinic laboratory is based on several ministerial regulations as stated above. It should be reiterated that they are the Ministery of Health Regulation Number 9 of 2014 for Clinic; the Ministery of Health Regulation Number 43 of 2013 on the Good Runing of Clinic laboratory and the Ministery of Health Regulation Number 411/MENKES/PER/III/2010 regarding Clinic Laboratory. It could be argued that these regulations are the legal basis in the Pancasila Legal System to fulfill the demand of the Law to have a proper standard of health service for the society in general and all the people of Indonesia. These regulations are considered as proper to make every possibility for the health service sector to undertake a further steps in order to achieve a high level, speedy, and satisfied of health service; and at the end of all justice is prevailed in Indonesia

It has been clearly stated in within the Indonesian system that clinic is a health service facility. This principle of health service is in accordance with Article 1 point 7 of the Act Number 36of 2009 on Health. Furthermore the Law has also defined that clinic is a facility or tool and/or a place which is used to undertake efforts to have a proper health service, whether thei are concerning promotive, preventive, curative or rehabilitative implemented by the central government, local government, and/or by the society itself.

Rules and Principles for the Setting Up and Running of a Clinic:-

Article 1 point 1 and Article 3 of the Ministery of Health Regulation Number 9 of 2014 regarding Clinic, contain a principle which reads that clinic is facilities for health services which organizing health services for individual in which basic medical services and/or specialists would be provided within. It has also been mentioned in the 
Ministerial Regulation that clinic is a place for a premium health services for society. Clinic could be running by the government, local government or society or the private sector. It should be mentioned here as well that appart from clinic, there are also other health services facilities such as hospitals, (poly) clinic or general clinic, and in Scotland this could be named as surgery (medical clinic)/balai pengobatan, joint practice of GP and several medical specialists or private GP. ${ }^{3}$ As one of the health services facilities clinic is considered as the society's most needed health resources to support the organization of health services accross the Country.

According to the law, to set up a clinic, one must be subjected to several requirements to be fulfilled. All of the requirements are stated in the Ministery of Health Regulation Number 9 of 2014 on Clinic. There must be a type of clinic, the requirement of a location, building, infrastructures (such as telephones, electricities, water, and so on, qualified manpower, equipment and facilities, farmacy and laboratory. Once all of these conditions are fulfilled by the intended party the government will issue the setting up and operational licences. Generally, these licenses are issued by the Local Government, as this authority will latter on having the power to exercise supervision on the clinic.

Article 32 section (1) and (2) of the Ministery of Health Regulation Number 9 of 2014 on Clinic has also reads that the running or organizing of a clinic in order to give an individual healt services is done for three main purposes: they are promotive, preventive, and currative. All of these types of health services might be conducted through temprary care, intensive care units, one day care or home care. Article 40 section (1) and (2) of the Ministery of Health Regulation Number 9 of 2014 on Clinic contain another principle that the management and control of the running of a clinic have to be conducted by the Ministery of Health, Governors, The Head of Health Office Department in the provinsial areas, the mayor or head of a district and these parties could be supported by professional organizations and the association of clinic.

As stated above, a laboratory must be instolled in a clinic. This principle is stated in the Article 24 section (1) until section (6) the Ninistery of Health Regulation Number 9 of 2014. The setting up a a clinic laboratory is mainly depend on the suitability of the proposed clinic and the availiabilities of temporary care unit, intensive care units and also depend on the type of the proposed clinic. The type of the laboratory is also depend on the type of the proposed clinic. It depends on the need of the clinic, and therefore it could be a premium clinic or medium clinic. In practice there has been a general and acceptable practice that the requirement to install an intensive care unit is only suit if the clinic is intended to be set up as a premium clinic, and in this case there should be a must that installment of a clinic laboratory mus be done for it. The clinic laboratory must be a premium one or a medium one and this is stated in the Ministery of Health Rgulation Number 411/Menkes/PER/III/2010.

The regulation that justify the existense of an integrated clinic or a clinic in clinic could be found in the Article 24 section (1) until section(6) of the Ministery of Health Rgulation Number 9 of 2014. Therea are several aspectsstated in the Article.(1) An intensive care clinic is obligated to runn the management and services for a clinic laboratory; (2) The temporary care clinic could, and in this terms is not necessarily required to runn or manage a clinic laboratory services; (3) the clinic laboratory as stated in the section (1) and section (2) of the Article 24 is a clinic laboratory for a premium health services according to the laws and regulations; (4) A premium clinic may be able to runn or manage a premium clinic services and the medium clinic services simultaneously; (5) The licensing granted to the clinic as stated in the section (3) and section (4) is an integrated licensing with the licensing granted to the clinic; (6) should a clinic is runn or manage with the facilities and infrastructures, and also manpower more then the required criterium and conditions of a clinic as stated in the section (3) and section (4), the clinic laboratory have to obtain a different licensing according to the existing laws and regulations.

Trilogy of the Health Services by an Integrated Clinic:-

According to the Ministery of Health Regulation Number 411/MENKES/PER/III/2010 on Clinic Laboratory, a health laboratory undertaking diagnose on spesiment for a clinic to obtain information concerning the health condition of an individual primarily in oderde to support the diagnose of the ilness, to cure a disease, and to restore health condition of a patient. All of these tasks can be done by the clinic laboratory set up and runn by the government, the local gobernment and private sectors. These clinics could integrate their clinics with the clinic which having its own clinic laboratory or set up each own laboratory clinic.

${ }^{3}$ CST Kansil, PengantarHukumKesehatan Indonesia, RinekaCipta, Jakarta, 1991, h. 35. 
The meaning or an integrated clinic laboratory is that the clinic laboratory being part of the clinic, or hospitals either it is a national hospitals or provisial hospitals, city or district hospitals, clinic, and so on. This is the patern which has become a legal model developed in practice to give a legal justification for a setting up and the running of an integrated clinic. ${ }^{4}$

The organizers of the clinic laboratory mus have a higly qualified manpower in order to runn the operational management for health services as precise asdemanded by the laws. Fotler, Ford and Heaton however, has argued for the same legal case. They argued that clinics, and to include in them the integrated clinic must have a high quality strategy, staff, and health service system. And this requirement stated by Fotler, Ford and Heaton has been coined as the trilogy of health services. ${ }^{5}$

The high quality requirement in strategy, staff, and health services by a clinic have to be complied with by the integrated clinic laboratory since the result of a laboratory diagnose can be seen as an important component in the chain of the heal services undertaken by a clinic. The result of the laboratory clinic diagnose can be used to make sure a diagnose conducted manually by general practitioners appart from the clinic laboratory. The result is also important to make certain the types of treatment that will be implemented by the doctors in the clinic and also to decide the necessary medication which should be taken by the patient, and prognosis. Therefore it is a legal requirement that the diagnose by a laboratory in an integrated clinic must be objective, and the diagnose must be conducted according to the real condition of the patient at the time of the diagnose (true value) in the integrated clinic as such.

The description mentioned above tells about the requirement of a laboratory diagnose in a clinic should be useful, and optimally needed. This could be achieved by a trustworthy and reliable diagnose in a laboratory, in which it must be in the clinic itself. Several conditions has been stated within the ministerial regulations. Among others are there must be a quality control management starting from the preanalysis, analysys and post analysis of the spesiment. Keeping the quality using the activity of quality control either it is done internally or externally; and the priority is done internally, within the klinik itself. This activity has been considered as a good laboratory practice/GLP. This standard of practice must be done by the staffs in the laboratory in every types of laboratory. Implementing this good laboratory practice/GLP is aim at the quality result of the activities done in the clinic laboratory. 6

By the principle of good laboratory practice/GLP is to mean that all the clinic laboratory must comply with the ${ }^{7}$ GLP. This GLP is done to obtain data on laboratory diagnose, the follow up and also the prognosis of the suspected disease and also the enviroment. The laboratory study must describe the whole work that has been done in the laboratory. Since the laboratory study could be used as the bencmark to be recommended for use by the interested party, in this case the doctors for the best interest of their patient.

The bencmark test will give the meaning that the good laboratory diagnose has been done selulerly, sub-selulerly, the existence of chemicals or phisical or the combination of all of them resulted from the laboratory study in the clinic laboratory. All of these data which resulted from the laboratory studi in the clinic must be documented directly by the clinic, and those data must be placed in the save and proper place as they must consist of original data and also copies concerning all the activities in the laboratory in the clinic. The spesiment must also be stored at the same clinic, as this is the part of the benchmark system.

\footnotetext{
${ }^{4}$ Eka Viora, Kebijakan dan Regulasi Penyelenggaraan Program Peningkatan Mutu dan Akreditasi Laboratorium Kesehatan, Semiloka Mutu PdsPatKLin XIV, Jakarta, 8 April 2016. Budi Mulyono, KinerjaManajemenOperasionalLaboratoriumKlinikdalamMenunjangUpayaPeningkatanMutudanKesela matanPasien, Buku Workshop ManajemenLaboratorium, PertemuanIlmiahtahunan XI, PDsPatKLin, Surabaya, h.3-4.

${ }^{6}$ Purwanto AP, PraktekLaboratoriumKesehatan yang Benar, PelatihanPemantapanMutuLaboratoriumKlinik, Imam BW, Purwanto AP danEkoJoko P editor, RS PantiWilasa Semarang dan PDs PatKLincabang Semarang, Semarang, 2010, h. 45-7.

${ }^{7}$ Ibid., h.48-9.
} 
The reseach has found that all of the demand in the good laboratory practice/GLP could also be found in the Ministery of Health Regulation Number 43 of 2013 on the Good Running of Clinic Laboratory. One aspect that is not manifested in the good laboratory practice/GLP but manifested in the ministerial regulation is that there must be a practical guidelines in every clinic laboratory to undertake every tasks that has to be done in it. This must be done as a part of the organization strategy for the clinic laboratory.

As generally known that in an organization, it is inevitaby that there must be manpower to runn the organization. By organization is to do the record, preparing and issuing a resut, reporting, keeping of the data and the authority to destroy all the data and documents at the proper time stated by the law. A good clinic laboratory must have the suitable rooms with a proper construction and facilities and all of the supporting equipment and infrastructure to store and keep all the data before the expired date as stated by the law.

The laboratory in the clinic must also having the laboratory equipments which have their own manuals to instruct their operation, to chose the proper tools or equipments. Therefore it is important not to neglect the vendor and also the suplier of the laboratory equipment. This in order to know who is responsible for what, particularly at the time oftroubleshooting, the broken down, and calibration of the equipment and also for their maintenance. There must also be materials support the working of the equipment in the clinic laboratory with its standard, types, tools to control, medium, and the maintenance and also its keeping. The laboratry must have all the spesiment, their manuals, preparation and the taking of them and also the precessing and the preparation and sending of the speciment.

The law, in this case the ministerial regulations has alsi dictates that a clinic laboratory must have its method of diagnose, the reason to choose its method of diagnose and also the evaluation of the result and process of the diagnose. Al af them must be a written document and will serve as a guidelines for cheking and control by the internal and external authority.

A clinic laboratory must also have the guaranty for the security of the laboratory. The security guaranty is reflected in the guidelines for the security, lay out of the room, safety equipments, the procedures for strerilization, disinfection, and decontamination. It must have a procedures to process the waste resulted from the laboratory, the keeping of the dangerous microorganism infectious, emergency equipment, and general safety for the people who work in the laboratory.

The research has shown that after the reconstruction of the laws and regulations as stated above, all of the requirement of a clinic laboratory in a clinic or an integrated clinic laboratory can be found in the Ministery of Health Regulation Number 411/MENKES/PER/III/2010 on Clinic Laboratory and the Ministery of Health Regulation Number 43 of 2013 on the Good Running of Laboratory Clinic. All of the requirement stated in the ministerial regulation as the manifestation of the sense of justice in the Indonesian Volksgeist governing the setting up and running of a clinic laboratory whether it is in the premium clinic or an integrated clinic laboratory.

\section{Conclusions:-}

The implementation of the regulation on the setting up and running of clinic laboratory in a clinic is in accordance with the law, such as the Ministery of Health Regulation Number 9 of 2014, the Ministery of Health Regulation Number 411/MENKES/PER/X/2010 on Clinic Laboratory, and the Ministery of Health Regulation Number 43 of 2013 on the Running of the Good Clinic Laboratory. Reading rule by rule of all the ministerial regulations as stated above, one could come to the conclusion that the setting up and the running of an integrated clinic laboratory still containing deficiencies, although legally acceptable.

In the setting up and running of a clinic laboratory in a clinic there must be a compliance with the requirements such as facilities and infrastructure, qualified manpower, good management, and the standardized procedural for medical services. However, all of the requirement has not been fully complied. Monitoring and evaluations are still needed to be conducted by the authority if the health sector, especially by the local government who has been granted with the power to control the health service in the contry.

Reconstruction is needed for the Article 24 section (1) to sectio (6) pf the Ministery of Health Regulation Number 9 of 2014 on Clinic that every clinic in a clinic or integrated clinic must have its own clinic laboratory. This is 
particularly important for the clinic which running the health service such as stated in the Article, the service of intensive medical care in the clinic.

\section{References:-}

Books and Journals:-

1. TeguhPrasetyo, Pancasila the Ultimate of All the Sources of Laws (A Dignified Justice Perspective), Journal of Law, Policy and Globalization, International Institute for Science, Technology and Education (IISTE), Vol. 54, October 2016.

2. Teguh Prasetyo, Criminal Liability of Doctor in Indonesia (From A Dignified Justice Perspective), International Journal of Advanced Research (IJAR), 1(10).

3. Prof. Dr. TeguhPrasetyo S. H. MS.i and Dr. Tri AstutiHandayani SH, Mhu,Legal Aid Principle: (Dignified Justice Theory Perspective),International Journal of Advanced Research (IJAR), 1(10).

4. Shallman, TeguhPrasetyo and Amin Purnawan, Public Service on Land Registration Based on the Dignified Justice, Journal of Advanced Research (IJAR), Int. J. Adv. Res.5(5), 154-163.

5. Teguh Prasetyo dan Abdul Halim Barkatullah, Ilmu Hukum dan Filsafat Hukum: Studi Pemikiran Sepanjang Zaman, Cetakan Keempat, Pustaka Pelajar, Yogyakarta, 2011.

6. Teguh Prasetyo \& Abdul Halim Barkatullah, Filsafat, Teori, \& Ilmu Hukum, Pemikiran Menuju Masyarakat yang Berkeadilan dan Bermartabat, Cetakan ke-1, RajaGrafindo Persada, Jakarta, 2012.

7. TeguhPrasetyo, HukumPidana, EdisiRevisi, CetakanKeempat, RajaGrafindoPersada, Jakarta, 2013.

8. 6. Teguh Prasetyo, HukumdanSistemHukumBerdasarkanPancasila, CetakanPertama, Media Perkasa, 2013.

9. Teguh Prasetyo, KriminalisasidalamHukumPidana, CetakanKetiga, Nusa Media, Bandung, 2013.

10. Teguh Prasetyo, TeoriKeadilanBermartbat: PerspektifTeoriHukum, CetakanPertama, Nusa Media, Bandung, 2015.

11. Teguh Prasetyo, SistemHukumPancasila:Sistem, SistemHukumdanPembentukanPeraturanPerundangUndangan di Indonesia, PerspektifTeoriKeadilanBermartabat, CetakanPertama, Nusa Media, Bandung, 2016.

12. Wandi Subroto; Prof. Dr. Teguh Prasetyo SH., M. Si and Dr. H. Jawade Hafidz S.H., M.H., Reconstructionofthe Lawsand Regulations Governing Authorityor Power of Legislatorsto Preventor Eradicate Corruption: (A Dignified JusticePerspective), International Journal of Advanced Research (IJAR), 5(6), 1240-1247.

\section{Related Laws \& Regulations:-}

1. The Republic of Indonesia Act Number 36 of 2014 on Health Professionals.

2. The Republic of Indonesia Act Number 36 of 2009 on Health.

3. The Republic of Indonesia Act Number 29 of 2004 on Medical Practice.

4. The Republic of Indonesia Act Number 39 of 1999 on Human Rights.

5. Ministery of Health of the Republic of Indonesia Regulation Number 9 of 2014 concerning Clinic.

6. Ministery of Health of the Republic of Indonesia Regulation Number 43 of 2013 on the Good Running of Clinic Laboratory.

7. Ministery of Health of the Republic of Indonesia Regulation Number 411/MENKES/PER/III/2010 on Clinic Laboratory. 